\title{
JIMMBA
}

\section{Pengaruh Good Corporate Governance, Leverage, Struktur Modal Dan Ukuran Perusahaan Terhadap Kinerja Keuangan Pada Perusahaan Sektor Aneka Industri Yang Terdaftar Di Bursa Efek Indonesia}

\author{
Mumtazatur Rahmatin', Ika Neni Kristanti ${ }^{2}$ \\ 1Sekolah Tinggi Ilmu Ekonomi Putra Bangsa \\ 2Sekolah Tinggi Ilmu Ekonomi Putra Bangsa \\ Email: mumtazatur.rahmatin@gmail.com
}

\begin{tabular}{l}
$\quad$ ARTICLE INFO \\
\hline Article History: \\
Received: July 27th 2020 \\
Accepted: August $15^{\text {st }} 2020$ \\
Published: August $31^{\text {st } 2020}$ \\
Keywords: \\
Kinerja Keuangan, \\
Dewan Komisaris \\
Independen, Komite \\
Audit, Leverage, Struktur \\
Modal, Ukuran \\
Perusahaan
\end{tabular}

\section{Pendahuluan}

Perkembangan industri di era global yang kini semakin pesat, membawa dampak pada persaingan setiap perusahaan industri. Saat ini perusahaan dituntut untuk meningkatkan dan mengembangkan kinerja perusahaan agar tetap bertahan dan bersaing dengan perusahaan lain. Untuk meningkatkan dan mengembangkan kinerja perusahaan, perusahaan harus memiliki tujuan yang jelas untuk menghadapi persaingan yang semakin ketat. Dengan adanya tujuan yang jelas, sehingga dapat membantu mengevaluasi dan memotivasi untuk meningkatkan kesejahteraan dan meningkatkan kinerja keuangan perusahaan.

Di Indonesia terdapat banyak perusahaan Manufaktur. Industri Manufaktur yang terdaftar di Bursa Efek Indonesia (BEI) dikelompokan kedalam tiga jenis sektor, yaitu sektor barang konsumsi, sektor aneka industri, dan sektor industri dasar dan kimia. Industri manufaktur khususnya sektor aneka industri merupakan salah satu bagian dari sektor perusahaan manufaktur, seluruh sub sektor yang ada pada sektor aneka industri merupakan para 
produsen dari produk-produk kebutuhan mendasar konsumen. Produk yang dihasilkan bersifat konsumtif dan disukai masyarakat sehingga para produsen dalam industri ini memiliki tingkat penjualan yang tinggi yang akan berdampak pada pertumbuhan sektor aneka industri.

Perusahaan manufaktur di Indonesia sedang menghadapi pesaingan global yang dikarenakan tingkat kurs dollar menguat naik, yang berdampak pada nilai rupiah dan perekonomian menjadi memburuk, hal ini dikarenakan efek perang dagang dengan banyaknya industri dari luar negri yang lebih murah sehingga berdampak pada ketatnya perdagangan dalam negri ditengah permintaan masyarakat yang masih lemah. Ditengah melemahnya Indeks Harga Saham Gabungan (IHSG), sektor aneka industri menguat mencapai 0.68 persen yang masih dibawah sektor tambang sebesar 0.78 persen (market.bisnis.com, 02/08/2018). Namun sektor aneka industri mengalami penurunan sebesar 0.92 persen (market.bisnis.com, 05/10/2018).

Berdasasarkan data Bursa Efek Indonesia (BEI) pergerakan harga saham emiten otomotif terus mengalami perlemahan pada tahun 2016 tampak sepi dibandingkan dengan sektor lainnya yang berimbas pada industri otomotif yaitu pergerakan harga saham emiten otomotif yang terus mengalami penurunan hingga 3,05 persen dari posisi 1.311,625 menjadi 1.272,541. PT Astra International Tbk (ASII), yang pada awalnya harga sahamnya bertengger pada level Rp7.850 menjadi melemah ke level Rp7.575 (cnnindonesia.com). Saham ASII merupakan saham dengan kapitalisasi pasar terbesar dalam indek sektor aneka industri sebesar Rp327,02 triliun (cnbcindonesia.com).

Tahun 2017 sektor aneka industri mengalami kenaikan. Kenaikan sektor aneka industri disebabkan karena naiknya kinerja keuangan PT Astra International Tbk (ASII) yang memuaskan pada awal 2017, dimana sektor aneka industri bangkit (rebound) yang sebelumnya terus bergerak negatif. Berdasarkan catatan di Bursa Efek Indonesia (BEI), indeks sektor aneka industri berada di level 1,536,728 atau naik signifikan 6,28 persen dibandingkan sebelumnya di level 1,445,926. Astra International emiten dengan kapitalis terbesar disektor aneka industri telah merilis laporan keuangan, dimana dalam laporan keuangan perusahaan tercatat meraup laba bersih sebesar Rp5,08 triliun, naik 63,34 persen dibandingkan dengan periode tahun sebelumnya Rp3,11 triliun. Dimana kondisi ini berbanding terbalik dengan kinerja awal tahun 2016 dimana laba bersih perusahaan tercatat turun sebesar 22.05 persen (cnnindonesia.com).

\section{Kajian Teori dan Telaah Literatur}

\section{Teori Agensi (Agency Theory)}

Teori keagenan menguraikan adanya hubungan antara pemisahan kepemilikan dan pengendalian perusahaan (Najmudin, 2011:37).(Hamdani, 2016:30) menjelaskan bahwa hubungan keagenan adalah sebuah kontrak antara menajer (agent) dengan investor (principal). Hubungan agency terjadi ketika satu orang atau lebih pemegang saham (principal) memperkerjakan orang lain (agent) untuk memberikan jasa dan kemudian mendelegasikan wewenang pengambilan keputusan kepada agent tersebut. Informasi internal dan prospek perusahaan di masa yang akan datang pastinya lebih diketahui oleh agent sebagai pengelola perusahaan dibandingkan dengan pemegang saham (principal). Oleh sebab itu agent sebagai pengelola perusahaan mempunyai kewajiban untuk memberikan sinyal kepada pemilik mengenai kondisi perusahaan. 


\section{Pecking Order Theory}

Pecking Order Theory menjelaskan mengapa perusahaan memiliki hirarki atau tingkat sumber dana yang paling disukai. Esensi teori ini adalah adanya dua jenis modal yaitu internal financing (laba ditahan) dan exsternal financing (hutang/obligasi dan saham). Perusahaan lebih memilih untuk menggunakan sumber dana internal (laba ditahan) daripada pendanaan eksternal. Apabila pendanaan eksternal diperlukan, perusahaan menerbitkan hutang lebih dahulu sedangkan penerbitan ekuitas dilakukan sebagai langkah terakhir. Penerbitan obligasi dipilih karena menimbulkan biaya lebih rendah dibandingkan penerbitan saham baru. Selain itu, pengumuman penerbitan saham baru diyakini dapat dipandang negatif oleh investor sehingga akan menurunkan harga saham (Najmudin, 2010: 302).

Pecking Order Theory menjelaskan bahwa perusahaan dengan tingkat profitabilitas tinggi utangnya rendah. Karena perusahaan yang profitabilitasnya tinggi memiliki sumber dana internal yang berlimpah. Perusahaan yang memiliki financial slack (dana yang dibangkitkan secara internal) yang cukup tidak perlu menerbitkan risk debt atau saham untuk mendanai proyek-proyek barunya sehingga masalah asimetri informasi tidak akan muncul (Sugiarto, 2009: 51).

\section{Kinerja Keuangan}

Menurut Ikatan Akuntan Indonesia (2007) Kinerja keuangan adalah kemampuan perusahaan dalam mengelola dan mengendalikan sumber daya yang dimilikinya. Menurut Extaliyus (2013), kinerja keuangan adalah gambaran setiap hasil ekonomi yang mampu diraih oleh perusahaan pada periode tertentu melalui aktivitas-aktivitas perusahaan untuk menghasilkan keuntungan secara efisien dan efektif, yang dapat diukur perkembangannya dengan mengadakan analisis terhadap data-data keuangan yang tercermin dalam laporan keuangan. Kinerja keuangan dalam penelitan ini digunakan sebagai variabel dependen yang menggunakan rasio profitabilitas yang diukur dengan proksi return on asset (ROA) adapun rumus perhitungannnya.

$$
R O A=\frac{\text { Net Income }}{\text { Total Assets }} \times 100 \%
$$

\section{Good Corporate Governance (GCG)}

FCGI (2003) menyatakan bahwa corporate governance adalah susunan aturan yang menentukan hubungan antara pemegang saham, manajer, kreditor, pemerintah, karyawan dan stakeholder internal dan eksternal yang lain sesuai dengan hak dan tanggung jawabnya. Good Corporate Governance dalam penelitian ini menggunakan proksi dengan dewan komisaris independen dan komite audit.

\section{Dewan Komisaris Independen}

Menurut Agoes dan Ardana (2014:110), komisaris independen adalah dewan komisaris yang tidak terafiliasi dengan manajemen, anggota komisaris lain, pemegang saham pengendali, serta bebas dari hubungan bisnis atau hubungan lainnya yang bisa mempengaruhi tugasnya untuk bertindak independen. Pengukuran proporsi dewan komisaris independen sebagai berikut:

$$
D K I=\frac{\text { Jumlah Komisaris independen }}{\text { jumlah seluruh komisaris }} \times 100 \%
$$




\section{Komite Audit}

Menurut Agoes dan Ardana (2014:110), komite audit adalah komite tertentu yang membantu tugas pengawasan dewan komisaris dalam pengelolaan perusahaan, salah satunya pengawasan dalam hal perlaporan keuangan perusahaan. Komite audit dalam penelitian ini dihitung dengan menggunakan proporsi sebagai berikut:

$$
\text { Komite Audit }=\sum \text { Komite Audit }
$$

\section{Leverage}

Leverage menggambarkan seberapa jauh perusahaan menggunakan sumber dana operasi melalui hutang. Leverage dalam penelitian ini diukur dengan rasio debt to equity ratio (DER). Debt to equity ratio (DER) merupakan rasio yang digunakan untuk mengukur seberapa besar total modal sendiri yang dibiayai dengan total hutang. Menurut Fahmi (2014: 73), rasio debt to equity ratio (DER) dapat dirumuskan sebagai berikut:

$$
\text { DER }=\frac{\text { Total Hutang }}{\text { Ekuitas }} \times 100 \%
$$

\section{Struktur Modal}

Menurut Fahmi (2018: 184), struktur modal merupakan gambaran dari bentuk proporsi finansial perusahaan yaitu antara modal yang dimiliki yang bersumber dari utang jangka panjang (long term liabilities) dan modal sendiri (shareholder's equity) yang menjadi sumber pembiayaan suatu perusahaan. Penelitian ini menggunakan debt to assets ratio (DAR). Debt to Assets Ratio (DAR), Rasio ini mengukur mengenai seberapa besar aktiva perusahaan yang dibiayai dengan utang. Semakin tinggi rasio ini maka semakin besar jumlah pinjaman yang digunakan untuk menghasilkan keuntungan perusahaan. Rasio struktur modal dapat dihitung dengan rumus:

$$
D A R=\frac{\text { Total Debt }}{\text { Total Assets }} \times 100 \%
$$

\section{Ukuran Perusahaan}

Pengertian ukuran perusahaan dikemukanan oleh Extaliyus (2013), “Ukuran perusahan merupakan nilai yang menunjukan besar kecilnya perusahaan. Terdapat berbagai proksi yang biasanya digunakan untuk mewakili ukuran perusahaan, total aset, jumlah penjualan, dan kapitalisasi pasar". Penelitian ini menggunakan ln total assets untuk mengukur ukuran perusahaan.

$$
\text { Ukuran Perusahaan }=\ln \text { total aset }
$$




\section{Kerangka Teori}

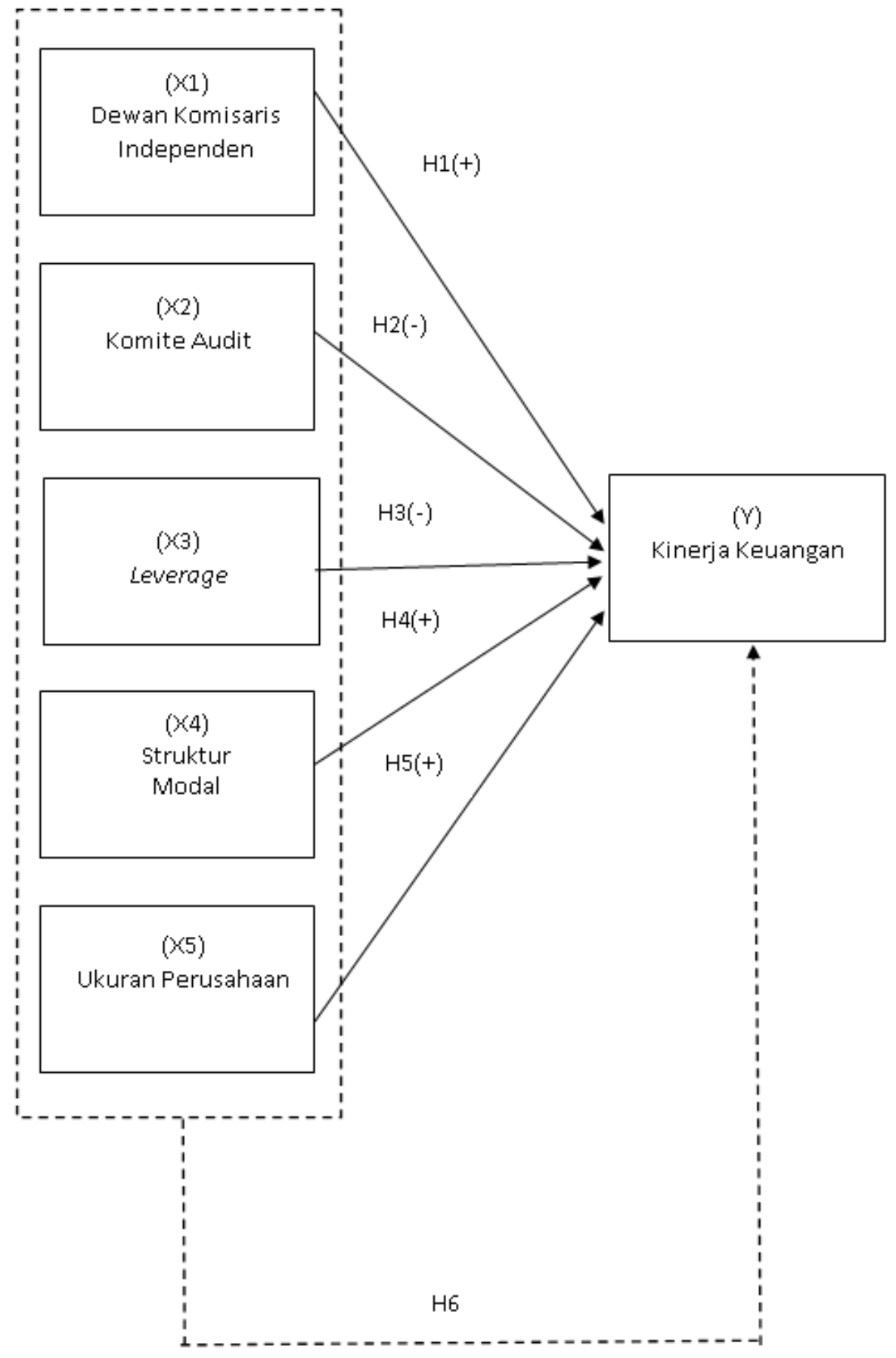

Gambar 1. Model Penelitian

\section{Hipotesis}

H1: Dewan Komisaris Independen berpengaruh positif terhadap kinerja keuangan

$\mathrm{H} 2$ : Komite Audit berpengaruh negatif terhadap kinerja keuangan

H3: Leverage berpengaruh negatif terhadap kinerja keuangan

H4: Struktur Modal berpengaruh positif terhadap kinerja keuangan 
H5: Ukuran Perusahaan berpengaruh positif terhadap kinerja keuangan

H6: Dewan Komisaris Independen, Komite Audit, Leverage, Struktur Modal, dan Ukuran Perusahaan berpengaruh secara simultan terhadap kinerja keuangan

\section{Metode Penelitian}

\section{Objek dan Subjek Penelitian}

Objek dalam penelitian ini adalah Good Cororate Governance (GCG) yang diproksikan oleh Dewan Komisaris Independen dan Komite Audit, Leverage, Struktur Modal, Ukuran Perusahaan, dan Kinerja Keuangan. Sedangkan subjek penelitian ini adalah Perusahaan Manufaktur Sektor Aneka Industri yang terdaftar di Bursa Efek Indonesia (BEI) periode 20162018.

\section{Populasi dan sampel}

Menurut Sugiyono (2010: 115), populasi merupakan wilayah generalisasi yang terdiri atas obyek atau subyek yang mempunyai kualitas dan karakteristik tertentu yang ditetapkan oleh peneliti untuk dipelajari dan kemudian ditarik kesimpulannya. Populasi yang digunakan dalam penelitian ini adalah perusahaan Manufaktur Sektor Aneka Industri yang terdaftar di BEI (Bursa Efek Indonesia).

Teknik pengambilan sampel dilakukan dengan metode purposive sampling. Purposive sampling adalah teknik penentuan sampel dengan pertimbangan tertentu (Sugiyono, 2007: 122). Beberapa pemilihan kriteria pemilihan sempel dalam penelitian ini adalah sebagai berikut:

Tabel 1. Kriteria pengambilan sampel

\begin{tabular}{clcc}
\hline No & \multicolumn{1}{c}{ Kriteria Pengambilan Sampel } & $\begin{array}{c}\text { Tidak } \\
\text { Masuk } \\
\text { Kriteria }\end{array}$ & $\begin{array}{c}\text { Jumlah } \\
\text { Perusahaan }\end{array}$ \\
\hline 1 & $\begin{array}{l}\text { Perusahaan yang terdaftar dalam Bursa Efek Indonesia } \\
\text { selama periode 2016-2018. }\end{array}$ & 45 \\
2 & $\begin{array}{l}\text { Perusahaan yang mempublikasikan laporan keuangan } \\
\text { secara berturut-turut selama periode 2016-2018. }\end{array}$ & 14 \\
\hline & Jumlah (31×3 tahun) & 93 \\
\hline
\end{tabular}

Sumber: Data diolah 


\section{Hasil dan Pembahasan}

\section{Analisis Statistic Descriptive}

Tabel 2. Descriptive Statistics

\begin{tabular}{lcrrrr}
\hline & $\mathrm{N}$ & Minimum & Maximum & Mean & $\begin{array}{c}\text { Std. } \\
\text { Deviation }\end{array}$ \\
\hline DKI & 93 & .29 & .67 & .4088 & .10910 \\
Komite Audit & 93 & 3 & 5 & 3.02 & .207 \\
DER & 93 & .01 & 31.24 & 1.6093 & 3.31037 \\
DAR & 93 & .08 & 5.07 & .7279 & .86457 \\
LN Total Aset & 93 & 12.48 & 29.06 & 20.5051 & 5.10850 \\
ROA & 93 & -.39 & .72 & .0085 & .09099 \\
Valid N & 93 & & & & \\
(listwise) & & & & & \\
\hline Sumber: Output IBM SPSS Statistic 25 (diolah), 2020. &
\end{tabular}

\section{Uji Asumsi Klasik}

\section{Uji Normalitas}

Tabel 3. Hasil Uji One-Sample Kolmogorov-Smirnov Test

\begin{tabular}{|c|c|c|}
\hline & & $\begin{array}{l}\text { Unstandardiz } \\
\text { ed Residual }\end{array}$ \\
\hline $\mathrm{N}$ & & 90 \\
\hline \multirow[t]{2}{*}{ Normal Parametersa,b } & Mean & .0000000 \\
\hline & $\begin{array}{l}\text { Std. } \\
\text { Deviation }\end{array}$ & 2.57358593 \\
\hline Most Extreme & Absolute & .052 \\
\hline \multirow[t]{2}{*}{ Dpifferences } & Positive & .045 \\
\hline & Negative & -.052 \\
\hline Test Statistic & & .052 \\
\hline Asymp. Sig. (2-tailed) & & $.200^{c, d}$ \\
\hline \multicolumn{3}{|c|}{$\begin{array}{l}\text { a. Test distribution is Normal. } \\
\text { b. Calculated from data. } \\
\text { c. Lilliefors Significance Correction. } \\
\text { d. This is a lower bound of the true significance. } \\
\text { Sumber: Output IBM SPSS Statistic } 25 \text { (diolah), } 2020 .\end{array}$} \\
\hline
\end{tabular}

Berdasarkan tabel 3, output SPSS menunjukkan bahwa nilai Asymp. Sig. (2 tailed) sebesar $0.200>0.05$. Maka hasil tersebut mennjukkan bahwa data dalam penelitian ini berdistribusi normal, Sehingga dapat disimpulkan bahwa model regresi dalam penelitian ini memenuhi asumsi normalitas. 


\section{Uji Multikolinearitas}

Tabel 4. Hasil Uji Multikolinearitas

\begin{tabular}{|c|c|c|c|c|c|}
\hline \multirow[b]{2}{*}{ Model } & \multicolumn{4}{|c|}{$\begin{array}{l}\text { Standardi } \\
\text { zed }\end{array}$} & \\
\hline & B & $\begin{array}{l}\text { Std. } \\
\text { Error }\end{array}$ & Beta & Tolerance & VIF \\
\hline (Constant) & 50.279 & 6.803 & & & \\
\hline DKI & -1.929 & 1.185 & -.069 & .983 & 1.018 \\
\hline Komite Audit & 6.774 & 5.261 & .055 & .982 & 1.018 \\
\hline DER & -.115 & .382 & -.018 & .509 & 1.965 \\
\hline DAR & .506 & .505 & .060 & .505 & 1.980 \\
\hline LN Total Aset & -23.914 & 1.115 & -.919 & .972 & 1.029 \\
\hline
\end{tabular}

a. Dependent Variable: ROA

Sumber: Output IBM SPSS Statistic 25 (diolah), 2020.

Berdasarkan tabel 4, dapat diketahui bahwa variabel independen Dewan Komisaris Indepeden, Komite Audit, DER, DAR dan Ukuran Perusahaan memiliki nilai tolerance $>0.10$ dan nilai VIF < 10. Jadi dapat disimpulkan bahwa tidak ada multikolinearitas antar model regresi.

\section{Uji Heteroskedastisitas}

Tabel 5 Hasil Uji Heteroskedastisitas

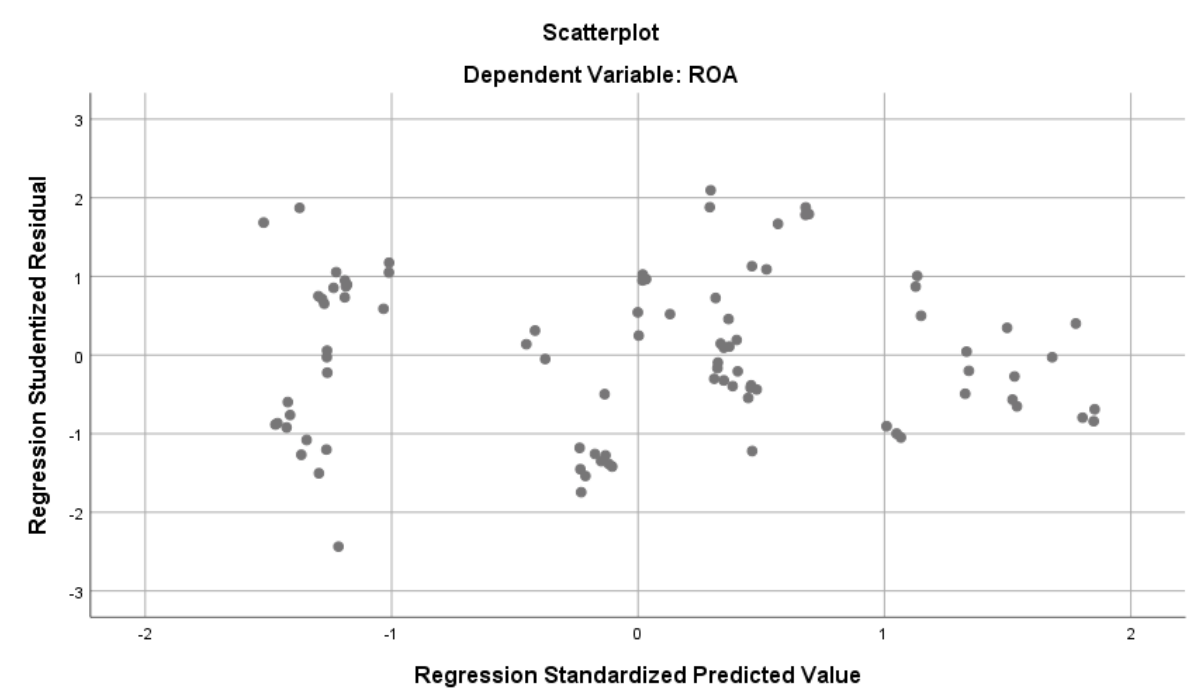

Sumber: Output IBM SPSS Statistic 25 (diolah), 2020.

Berdasarkan tabel 5, grafik scatterplot terlihat titik-titik menyebar secara acak serta menyebar diatas dan dibawah angka 0 pada sumbu Y. Hal ini dapat disimpulkan bahwa tidak terjadi heteroskedastisitas pada model regresi. 


\section{Uji Autokorelasi}

Tabel 6 Hasil Uji Run Test

\begin{tabular}{lr}
\hline & \multicolumn{2}{c}{ Unstandardized } \\
& Residual \\
\hline Test Value & -.07100 \\
Cases < Test Value & 45 \\
Cases >= Test Value & 45 \\
Total Cases & 90 \\
Number of Runs & 44 \\
Z & -.424 \\
Asymp. Sig. (2-tailed) & .672 \\
\hline
\end{tabular}

a. Median

Sumber: Output IBM SPSS Statistic 25 (diolah), 2020.

Beradasarkan tabel 6, hasil uji run test menunjukkan bahwa nilai Asymp. Sig (2-tailed) sebesar 0.672 diatas $0.05(0.672>0.05)$ yang artinya bahwa model regresi dalam penelitian ini tidak terdapat gejala atau masalah autokorelasi.

\section{Analisis Regresi Linear Berganda}

Tabel 7 Uji Analisis Regresi Linear Berganda

\begin{tabular}{|c|c|c|c|c|c|c|}
\hline \multirow{2}{*}{\multicolumn{2}{|c|}{ Model }} & \multicolumn{2}{|c|}{$\begin{array}{l}\text { Unstandardized } \\
\text { Coefficients }\end{array}$} & \multirow{2}{*}{$\begin{array}{c}\begin{array}{c}\text { Standardized } \\
\text { Coefficients }\end{array} \\
\text { Beta }\end{array}$} & \multirow[b]{2}{*}{$\mathrm{t}$} & \multirow[b]{2}{*}{ Sig. } \\
\hline & & B & $\begin{array}{l}\text { Std. } \\
\text { Error }\end{array}$ & & & \\
\hline 1 & (Constant) & 50.279 & 6.803 & & 7.390 & 0.000 \\
\hline & DKI & -1.929 & 1.185 & -0.069 & -1.628 & 0.107 \\
\hline & Komite Audit & 6.774 & 5.261 & 0.055 & 1.288 & 0.201 \\
\hline & DER & -0.115 & 0.382 & -0.018 & -0.301 & 0.764 \\
\hline & DAR & 0.506 & 0.505 & 0.060 & 1.003 & 0.319 \\
\hline & LN Total Aset & -23.914 & 1.115 & -0.919 & -21.439 & 0.000 \\
\hline
\end{tabular}

a. Dependent Variable: ROA

Sumber: Output IBM SPSS Statistic 25 (diolah), 2020.

Berdasarkan tabel 7 dapat diketahui persamaan regresi dalam penelitian ini adalah sebagai berikut:

$$
\begin{aligned}
Y & =a+b_{1} X_{1}+b_{2} X_{2}+b_{3} X_{3}+b_{4} X_{4}+b_{5} X_{5}+e \\
& =50.279-1.929+6.774-0.115+0.506-23.914+e
\end{aligned}
$$




\section{Hipotesis}

\section{Uji Parsial (Uji T)}

Tabel 8 Uji Parsial

\begin{tabular}{|c|c|c|c|c|c|c|}
\hline \multirow{3}{*}{\multicolumn{2}{|c|}{ Tod }} & \\
\hline & & \multicolumn{2}{|c|}{$\begin{array}{l}\text { Unstandardized } \\
\text { Coefficients }\end{array}$} & \multirow{2}{*}{$\begin{array}{c}\mathrm{d} \\
\text { Coefficients } \\
\text { Beta }\end{array}$} & \multirow[b]{2}{*}{$\mathrm{t}$} & \multirow[b]{2}{*}{ Sig. } \\
\hline & & B & $\begin{array}{l}\text { Std. } \\
\text { Error }\end{array}$ & & & \\
\hline \multirow[t]{6}{*}{$\overline{1}$} & (Constant) & 50.279 & 6.803 & & 7.390 & .000 \\
\hline & DKI & -1.929 & 1.185 & -.069 & -1.628 & .107 \\
\hline & Komite Audit & 6.774 & 5.261 & .055 & 1.288 & .201 \\
\hline & DER & -.115 & .382 & -.018 & -.301 & .764 \\
\hline & DAR & .506 & .505 & .060 & 1.003 & .319 \\
\hline & LN Total Aset & -23.914 & 1.115 & -.919 & -21.439 & .000 \\
\hline
\end{tabular}

a. Dependent Variable: ROA

Sumber: Output IBM SPSS Statistic 25 (diolah), 2020.

Berdasarkan tabel 8 hasil uji parsial (uji t) masing-masing variabel independen dalam penelitian ini adalah sebagai berikut:

1. Variabel dewan komisaris independen (DKI) diperoleh $t_{\text {hitung }}-1.628<t_{\text {tabel }} 1.988$ dengan tingkat signifikan sebesar $0.107>0.05$, yang berarti variabel dewan komisaris independen (DKI) tidak berpengaruh terhadap kinerja keuangan.

2. Variabel komite audit diperoleh $t_{\text {hitung }} 1.288<t_{\text {tabel }} 1.988$ dengan tingkat signifikan sebesar $0.201>0.05$, yang berarti variabel komite audit tidak berpengaruh terhadap kinerja keuangan.

3. Variabel leverage diperoleh $t_{\text {hitung }}-0.301<t_{\text {tabel }} 1.988$ dengan tingkat signifikan sebesar $0.764>0.05$, yang berarti variabel leverage tidak berpengaruh terhadap kinerja keuangan.

4. Variabel struktur modal diperoleh $t_{\text {hitung }} 1.003<t_{\text {tabel }} 1.988$ dengan tingkat signifikan sebesar $0.319>0.05$, yang berarti variabel struktur modal tidak berpengaruh terhadap kinerja keuangan.

5. Variabel ukuran perusahaan diperoleh $t_{\text {hitung }}-21.439>t_{\text {tabel }} 1.988$ dengan tingkat signifikan sebesar $0.000<0.05$, yang berarti variabel ukuran perusahaan berpengaruh negatif terhadap kinerja keuangan.

\section{Uji Simultan (Uji F)}

Tabel 9 Uji Simultan

\begin{tabular}{|c|c|c|c|c|c|c|}
\hline \multicolumn{2}{|c|}{ Model } & $\begin{array}{l}\text { Sum of } \\
\text { Squares }\end{array}$ & $\mathrm{df}$ & \multicolumn{2}{|l|}{ Mean } & Sig. \\
\hline 1 & Regression & 3336.990 & 5 & 667.398 & 95.104 & $.000^{\mathrm{b}}$ \\
\hline & Residual & 589.478 & 84 & 7.018 & & \\
\hline & Total & 3926.468 & 89 & & & \\
\hline
\end{tabular}

a. Dependent Variable: ROA

b. Predictors: (Constant), LN Total Aset, DKI, Komite Audit, DER, DAR

Sumber: Output IBM SPSS Statistic 25 (diolah), 2020. 
Berdasarkan tabel 9, hasil uji f diperoleh nilai $\mathrm{F}_{\text {hitung }}$ sebesar 95.104 dan $\mathrm{F}_{\text {tabel }}$ 2,32 dengan tingkat signifikansi sebesar $0.000<0.05$. Sehingga didapatkan $95.104>2,32\left(\mathrm{~F}_{\text {hitung }}>\mathrm{F}_{\text {tabel }}\right)$, maka dapat disimpulkan bahwa dewan komisaris independen (DKI), komite audit, leverage, struktur modal, dan ukuran perusahaan secara simultan berpengaruh terhadap kinerja keuangan.

\section{Koefisien Determinasi $\left(R^{2}\right)$}

Tabel 10 Hasil Uji Koefisien Determinasi $\left(\mathbf{R}^{2}\right)$

\begin{tabular}{|c|c|c|c|c|}
\hline Model & $\mathrm{R}$ & R Square & $\begin{array}{c}\text { Adjusted R } \\
\text { Square }\end{array}$ & $\begin{array}{l}\text { Std. Error of the } \\
\text { Estimate }\end{array}$ \\
\hline$\overline{1}$ & $.922^{a}$ & .850 & .841 & 2.64907 \\
\hline
\end{tabular}

Sumber: Output IBM SPSS Statistic 25 (diolah), 2020.

Berdasarkan tabel 10 hasil Ouput SPSS bahwa $R$ Square $\left(R^{2}\right)$ sebesar 0.841 atau $84.1 \%$. Artinya variabel independen dewan komisaris independen (DKI), komite audit, leverage, struktur modal, dan ukuran perusahaan berkontribusi sebesar $84.1 \%$ terhadap kinerja keuangan yang merupakan dari variabel dependen dari penelitian ini. Sedangkan sisanya $(100 \%-84.1 \%)$ sebesar $15.9 \%$ dapat dipengaruhi oleh variabel-variabel lain diluar penelitian ini.

\section{Pembahasan}

\section{Pengaruh Dewan Komisaris Independen (DKI) Terhadap Kinerja Keuangan}

Berdasarkan hasil pengujian pada tabel 8 dapat diketahui bahwa dewan komisaris independen diperoleh thitung $-1.628<$ ttabel 1.988 dengan tingkat signifikan sebesar $0.107>$ 0.05 , yang berarti variabel dewan komisaris independen (DKI) tidak berpengaruh terhadap kinerja keuangan. Dewan komisaris independen tidak memberikan kontribusi yang positif terhadap kinerja keuangan. Hal ini berarti bahwa jumlah besar kecilnya dewan komisaris independen dalam perusahaan tidak dapat menjamin baiknya pengawasan, pengelolaan, dan pengambilan keputusan yang akurat dalam perusahaan. Pengangkatan komisaris independen dalam perusahaan bertujuan untuk meningkatkan pengawasan demi menciptakan kegiatan usaha yang transparan dan menghindarkan dari munculnya perilaku menyimpang manajer. Pengangkatan komisaris independen cenderung dianggap sebagai formalitas dalam penerapan GCG terbukti masih ada perusahaan yang memiliki 1 komisaris independen.

Hasil penelitian ini sejalan dengan penelitian terdahulu yang dilakukan oleh Aziz (2017) yang menemukan hasil bahwa dewan komisaris independen tidak berpengaruh terhadap kinerja keuangan. Akan tetapi hasil penelitian ini tidak sejalan dengan penelitian terdahulu yang dilakukan oleh Saifi (2017) yang menemukan hasil bahwa dewan komisaris independen berpengaruh terhadap kinerja keuangan. 


\section{Pengaruh Komite Audit Terhadap Kinerja Keuangan}

Berdasarkan hasil pengujian pada tabel 8 dapat diketahui bahwa komite audit diperoleh $t_{\text {hitung }}$ $1.288<t_{\text {tabel }} 1.988$ dengan tingkat signifikan sebesar $0.201>0.05$, yang berarti variabel komite audit tidak berpengaruh terhadap kinerja keuangan.

Hasil penelitian ini menunjukkan bahwa komite audit tidak bengaruh terhadap kinerja keuangan. Hal ini terjadi karena adanya kemungkinan bahwa pembentukan komite audit dalam perusahaan hanya atas dasar regulasi, dimana setiap perusahaan harus membentuk komite audit. Keberadaan komite audit tidak bisa menjamin kualitas keuangan, fungsi pengawasan dan pengendalian pada manajemen perusahaan sehingga tidak berpengaruh terhadap kinerja keuangan. Hasil penelitian ini sejalan dengan penelitian yang dilakukan oleh Aziz (2017) yang menemukan hasil bahwa komite audit tidak berpengaruh terhadap kinerja keuangan. Akan tetapi hasil penelitian ini tidak sejalan dengan penelitian terdahulu yang dilakukan oleh Atmaja (2018) yang menemukan hasil bahwa komite audit berpengaruh terhadap kinerja keuangan.

\section{Pengaruh Leverage Terhadap Kinerja Keuangan}

Berdasarkan hasil pengujian pada tabel 8 dapat diketahui bahwa leverage diperoleh $t_{\text {hitung }}$ $0.301<$ ttabel 1.988 dengan tingkat signifikan sebesar $0.764>0.05$, yang berarti variabel leverage tidak berpengaruh terhadap kinerja keuangan.

Perusahaan yang memiliki kewajiban yang berupa beban atas aktiva yang dibiayai oleh utang yang tinggi, dapat menyebabkan biaya modal yang tinggi. Maka leverage akan mengurangi jumlah modal sendiri yang akan digunakan untuk membiayai tingkat penggunaan utang yang cukup. Besar kecilnya jumlah utang atas ekuitas yang dimiliki oleh perusahaan tidak akan berpengaruh pada besar kecilnya laba yang diperoleh perusahaan. Oleh karena itu untuk meningkatkan laba maka perusahaan tidak perlu meningkatkan profitabilitas dan tidak perlu meningkatkan jumlah utang atas ekuitas, karena besar kecilnya leverage tidak berpengaruh terhadap kinerja keuangan. Hasil penelitian ini sejalan dengan penelitian yang dilakukan oleh Aziz (2017) yang menemukan hasil bahwa leverage tidak berpengaruh terhadap kinerja keuangan. Akan tetapi hasil penelitian ini tidak sejalan dengan hasil penelitian terdahulu yang dilakukan oleh Tambunan (2018) yang menemukan hasil bahwa leverage berpengaruh terhadap kinerja keuangan.

\section{Pengaruh Struktur Modal Terhadap Kinerja Keuangan}

Berdasarkan hasil pengujian pada tabel 8 dapat diketahui bahwa struktur modal diperoleh thitung $1.003<$ ttabel 1.988 dengan tingkat signifikan sebesar $0.319>0.05$, yang berarti variabel struktur modal tidak berpengaruh terhadap kinerja keuangan. Semakin tinggi struktur modal maka semakin besar resiko keuangannya. Besarnya resiko yang dimaksud adalah kemungkinan terjadinya gagal bayar (defaul) karena perusahaan terlalu banyak melakukan pendanaan aktiva yang diperoleh dari hutang. Dengan adanya gagal banyar maka perusahaan akan mengeluarkan biaya untuk mengatasi masalah. Semakin rendah struktur modal, maka semakin tinggi kemampuan perusahaan untuk membayar seluruh kewajibannya yang berarti bahwa sebagian aktiva perusahaan dibiayai oleh hutang. Struktur modal yang menurun disebabkan peningkatan total aktiva yang lebih besar dibandingkan dengan peningkatan hutang sehingga dapat menurunkan beban hutang yang mengakibatkan keuntungan perusahaan yang dihasilkan meningkat. 
Tidak adanya pengaruh struktur modal terhadap kinerja keuangan kemungkinan ada perusahaan sektor aneka industri yang memiliki hutang dan laba yang tinggi, akan tetapi ada juga perusahaan yang memiliki hutang yang tinggi dan laba rendah, oleh karena itu tinggi rendahnya struktur modal pada perusahaan tidak berpengaruh terhadap kinerja keuangan perusahaan.

Hasil penelitian ini sejalan dengan penelitian yang dilakukan oleh Faidah (2016) yang menemukan hasil bahwa struktur modal tidak berpengaruh terhadap kinerja keuangan. Akan tetapi hasil penelitian ini tidak sejalan dengan penelitian terdahulu yang dilakukan oleh Swandari (2016) yang menemukan hasil bahwa struktur modal berpengaruh terhadap kinerja keuangan.

\section{Pengaruh Ukuran Perusahaan Terhadap Kinerja Keuangan}

Berdasarkan hasil pengujian pada tabel 8 dapat diketahui bahwa ukuran perusahaan diperoleh thitung -21.439 > ttabel 1.988 dengan tingkat signifikan sebesar $0.000<0.05$, yang berarti variabel ukuran perusahaan berpengaruh negatif terhadap kinerja keuangan. Perusahaan dengan aset yang besar dapat dengan mudah mengakses pasar modal. Dengan adanya kemudahan mengakses pasar modal, perusahaan tersebut memiliki fleksibilitas dan kemampuan mendapatkan dana (Ernawati, 2010). Besarnya ukuran perusahaan belum tentu perusahaan memiliki kinerja yang baik, karena perusahaan dengan ukuran yang besar juga belum tentu memiliki sistem kerja yang baik. Hal ini dapat disebabkan karena ukuran perusahaan yang besar belum didukung pengelolaan yang baik. Ukuran perusahaan yang besar tidak dapat digunakan sebagai jaminan bahwa perusahaan memiliki kinerja yang baik.

Hasil penelitian ini sejalan dengan penelitian yang dilakukan oleh Zamzami (2018) yang menemukan hasil bahwa ukuran perusahaan berpengaruh negatif terhadap kinerja keuangan. Tetapi penelitian ini tidak sejalan dengan penelitian terdahulu yang dilakukan oleh Christiawan (2017) yang menemukan hasil bahwa ukuran perusahaan tidak berpengaruh terhadap kinerja keuangan.

\section{Penutup dan Saran}

\section{Simpulan}

Berdasarkan hasil analisis data dan pembahasan yang telah diuraikan, maka kesimpulan yang dapat diambil yaitu sebagai berikut:

a. Dewan komisaris independen tidak berpengaruh terhadap kinerja keuangan. Besar kecilnya jumlah dewan komisaris independen dalam perusahaan tidak dapat menjamin baiknya pengawasan, pengelolaan, dan pengambilan keputusan yang akurat dalam perusahaan.

b. Komite audit tidak berpengaruh terhadap kinerja keuangan. Pembentukan komite audit dalam perusahaan hanya atas dasar regulasi, dimana setiap perusahaan harus membentuk komite audit.

c. Leverage tidak berpengaruh terhadap kinerja keuangan. Perusahaan dengan tingkat utang yang tinggi maka semakin tinggi pula tingkat resiko yang dihadapi perusaahaan.

d. Struktur modal tidak berpengaruh terhadap kinerja keuangan. Tinggi rendahnya struktur modal tidak berpengaruh terhadap kinerja keuangan. 
e. Ukuran perusahaan berpengaruh negatif terhadap kinerja keuangan. Semakin besar ukuran perusahaan belum tentu perusahaan memiliki kinerja yang baik, karena perusahaan dengan ukuran yang besar juga belum tentu memiliki sistem kerja yang baik.

f. Dewan komisaris independen (DKI), komite audit, leverage, struktur modal dan ukuran perusahaan secara simultan berpengaruh teradap kinerja keuangan pada perusahaan sektor aneka industri yang terdaftar di Bursa Efek Indonesia periode 2016-

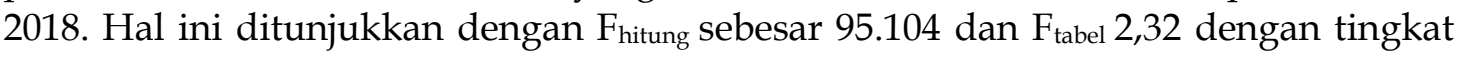
signifikansi sebesar $0.000<0.05$.

\section{Keterbatasan}

a. Perusahaan yang dijadikan sebagai sampel peelitian hanya terbatas pada sektor aneka industri, sehingga kurang mewakili seluruh perusahaan yang terdaftar di Bursa Efek Indonesia. Serta periode yang dilakukan dalam penelitian ini terlalu singkat yaitu hanya selama tiga tahun yaitu dari tahun 2016 sampai dengan 2018.

b. Penelitian ini hanya menggunakan beberapa variabel penelitian yakni good corporate governance, leverage, struktur modal dan ukuran perusahaan.

\section{Referensi}

Agoes, S., \& Ardana, I. C. (2009). Etika Bisnis dan Profesi. Jakarta: Salemba Empat

Atmaja, Y. W. (2018). Analisis Pengaruh Good Corporate Governance, Ukuran Perusahaan, dan Leverage Perusahaan Terhadap Kinerja Keuangan Sektor Perbankkan (Studi Pada Perusahaan Perbankkan Yang Terdaftar Di Bursa Efek Indonesia (BEI) Tahun 20092013). Performance: Jurnal Personalia, Financial, Operasional, Marketing dan Sistem Informasi, 21(1), 1-15.

Azis, A. (2017). Pengaruh Good Corporate Governance, Struktur Modal, Dan Leverage Terhadap Kinerja Keuangan Perusahaan Pada Sektor Pertambangan Yang Terdaftar Di Bursa Efek Indonesia Tahun 2011-2015. Jurnal Ilmu Manajemen (JIM), 5(3).

Fahmi, I. (2012). Pengantar Manajemen Keuangan. Bandung: Alfabeta.

Fahmi, I. (2018). Pengantar Manajemen Keuangan. Bandung: Alfabeta.

Faidah, F. (2018). Analisa Profitabilitas, Perputaran Piutang, dan Struktur Modal Terhadap Kinerja Keuangan Perusahaan Manufaktur Yang Terdaftar Di Bursa Efek Indonesia. Jurnal Studi Manajemen Bisnis, 2(2).

Fitriani, E., \& Zamzami, Z. (2018). Analisis Pengaruh Ukuran Perusahaan, Leverage dan Good Corporate Governance Terhadap Kinerja Keuangan (Studi Kasus Perusahaan Sektor Utama di Bursa Efek Indonesia Tahun 2011-2016). Jurnal Akuntansi \& Keuangan Unja, $3(6), 14-24$.

Ghozali, I. (2018). Aplikasi Analisis Multivariete dengan Program IBM SPSS 25. Semarang: Universitas Diponegoro.

Goldwin, J., \& Christiawan, Y. J. (2017). Pengaruh penerapan corporate governance terhadap kinerja keuangan perusahaan dengan ukuran perusahaan dan umur perusahaan sebagai variabel kontrol. Business Accounting Review, 5(2), 217-228. 
Imadudin, Z., \& Swandari, F. (2016). Pengaruh Struktur Modal terhadap Kinerja Perusahaan. JWM (Jurnal Wawasan Manajemen), 2(1), 81-96.

Indarti, M. K., \& Extaliyus, L. (2013). Pengaruh Corporate Gorvernance Preception Index (CGPI), Struktur Kepemilikan, Dan Ukuran Perusahaan Terhadap Kinerja Keuangan. Jurnal Bisnis dan Ekonomi, 20(2).

Jessica Talenta, A. T. (2018). Pengaruh Ukuran Perusahaan, Leverage dan Struktur Modal terhadap Kinerja Keuangan Perusahaan (Studi Pada Perusahaan Manufaktur Sektor Aneka Industri tahun 2012-2016) (Doctoral dissertation, Diponegoro University).

Musthafa. (2017). Manajemen Keuangan. Yogyakarta: Andi.

Sarafina, S., \& Saifi, M. (2017). Pengaruh Good Corporate Governance terhadap kinerja keuangan dan nilai perusahaan (Studi pada Badan Usaha Milik Negara (BUMN) yang terdaftar di Bursa Efek Indonesia periode 2012-2015). Jurnal Administrasi Bisnis, 50(3), 108-117.

Sugiyono. (2010). Metode Penelitian Kuantitatif, Kualitatif, dan RAD. Cetak Ke-II. Bandung. Penerbit Alfabeta.

Wahyuni, F., \& Erawati, T. (2019). Pengaruh Corporate Governance, Ukuran Perusahaan, dan Leverage Terhadap Kinerja Keuangan Perusahaan di Bursa Efek Indonesia (Studi Kasus Perusahaan Manufaktur yang Terdaftar di Bursa Efek Indonesia Periode 20132017). Jurnal Akuntansi Pajak Dewantara, 1(2), 113-128.

Widyati, M. F. (2013). Pengaruh dewan direksi, komisaris independen, komite audit, kepemilikan manajerial dan kepemilikan institusional terhadap kinerja keuangan. Jurnal ilmu manajemen, 1(1), 234-249. 